\title{
Functional divergence effects of intercropped faba bean and maize in organic production for forage increase mineral contents and reduces leaf spots
}

\author{
Eva Stoltz ${ }^{1}$, Ann-Charlotte Wallenhammar ${ }^{1}$ and Elisabet Nadeau ${ }^{2,3}$ \\ ${ }^{1}$ Research \& Development, Rural Economy and Agricultural Society|HS Konsult AB, Box 271, 70145 Örebro, Sweden \\ ${ }^{2}$ Department of Animal Environment and Health, Swedish University of Agricultural Sciences, Box 234, 53223 Skara, Sweden \\ ${ }^{3}$ Research \& Development, Rural Economy and Agricultural Society Sjuhärad, Rådde Gård, Box 5007, 51405 Länghem, Sweden \\ e-mail: eva.stoltz@hush.se
}

\begin{abstract}
Multispecies cropping systems contribute to sustainable agriculture with multiple ecosystem services. Effects of intercropping of organically managed maize and faba beans to silage on acquisition of mineral nutrients in shoots of both crops and on leaf spot progression in faba beans were investigated. Three field experiments were performed with maize and faba bean intercropped or grown separately. Intercropping increased shoot concentrations of $\mathrm{K}$, $\mathrm{Ca}, \mathrm{Mg}, \mathrm{Na}, \mathrm{S}$ and $\mathrm{B}$ in faba bean, and shoot concentrations of $\mathrm{Cu}, \mathrm{Zn}$ and $\mathrm{Mo}$ in maize. Thus, the ecological complementary effects enhance feed quality. Disease severity index (DSI) of leaf spots in faba beans was reduced by intercropping by $42-57 \%$, partly due to an increased $\mathrm{Cu}$ acquisition at sites where the $\mathrm{Cu}$ availability was low. There was a significant negative linear relationship between $\mathrm{Cu}$ concentration in shoots and DSI of leaf spots. Total uptake of mineral nutrients per land area was greater in the intercropping system with a total LER $>1$ for all mineral nutrients, except for $\mathrm{P}, \mathrm{Ca}$ and $\mathrm{Mn}$ at one of the sites. Increased nutrient use efficiency, due to facilitative uptake from the soil, and the production of crops with higher contents of minerals compared with monocropping, are benefits of intercropped maize and faba beans.
\end{abstract}

Key words: intercrop, maize, faba bean, mineral nutrients, leaf spot (Botrytis fabae, Ascochyta fabae).

\section{Introduction}

Cropping two or more species on the same land area provides multiple ecosystem services improving the sustainability in agricultural production systems. The crops may be intercropped in a forage ley with a mixture of species, or different crop species grown in separate rows, or in wide strips. Facilitative root interactions between crop species in an intercropping system may generate benefits such as greater biomass yield per land area (Jannasch and Martin 1999, Hauggaard-Nielsen and Jensen 2005, Li et al. 2014). The mechanisms behind the increased yields in intercropping systems may be due to the combination of the species functional traits involved in nutrient acquisition reviewed by Faucon et al. (2017). Thus, plant acquisition of e.g. N and P are improved by interspecific facilitation i.e. the functional trait of one plant species improves the nutrient uptake of another species that results in an increased efficiency in the use of nutrients in the soil (Li et al. 2007, Xia et al. 2013, Li et al. 2014). Maize (Zea mays $\mathrm{L}$ ) and faba bean (Vicia faba $\mathrm{L}$ ) often result in enhanced yields, with land equivalent ratios $>1$ when intercropped (Li et al. 2011, Stoltz and Nadeau 2014).

The uptake of other mineral nutrients besides $\mathrm{N}$ and $\mathrm{P}$ may also be affected by intercropping, but may be influenced by the source of $\mathrm{P}$ applied. Many legumes are known to have the functional trait to produce root exudates increasing the plant availability of nutrients in the soil that may also be used by the companion crop (Hinsinger et al. 2011). Concentrations of $\mathrm{Cu}, \mathrm{Mg}, \mathrm{Mn}$ and $\mathrm{Zn}$ increased in wheat and chickpea when inorganic $\mathrm{P}$ was supplied, but only in wheat when sodium phytate was supplied (Li et al. 2004b). The translocation of nutrients within the plant may also be affected by intercropping. For example, concentrations of Fe, Mn, $\mathrm{Cu}$ and $\mathrm{Zn}$ of whole maize shoots increased by intercropping maize with faba bean, chickpea, soybean or turnip compared with monocropped maize, while the concentrations in maize grain decreased, except in the maize/turnip intercrop where the concentrations were similar to that of monocropped maize (Xia et al. 2013). Furthermore, concentrations of $P, K, F e, Z n$ and $\mathrm{Mn}$ increased in wheat shoot when intercropped with chickpea or lentil, whereas N, P, K and Fe increased in the wheat grain compared with monocropped wheat (Gunes et al. 2007). 
In faba bean problems with plant pathogens are common and diseases such as chocolate spot (Botrytis fabae) and Ascochyta blight (Ascochyta faba), are commonly present in Swedish faba crops and may cause substantial yield reductions (Sahile et al. 2008a, Sillero et al. 2010, Akhter 2014). Both diseases are caused by seed-and soil borne pathogens and may also be spread by infected plant material. Previous investigations have shown that intercropping different species may reduce the presence of plant pathogens, an ecosystem service that reduce the need of pesticides and improves the sustainability of agricultural practices. A reduction of chocolate spot development was found when faba bean was intercropped with barley or maize compared with monocropped faba bean due to the presence of a non host species in the intercropping system (Sahile et al. 2008b). The reduction of chocolate spot development was even greater in the faba bean/maize mixture compared with the faba bean/ barley mixture and the suggested reason was a more aerated crop stand structure (Sahile et al. 2008b). Considering plant functional traits, the decomposition of plant material that the pathogen thrive on may be elevated in a multispecies cropping system, thus the conditions for the pathogen will be limited and the availability of nutrients will increase (Faucon et al. 2015).

Defense mechanisms in plants may be strengthened by sufficient concentrations of mineral nutrients and numerous investigations confirm that improved acquisition of nutrients reduce disease development in crops (Engelhard 1993, Datnoff et al. 2007, Huber and Haneklaus 2007, Dordas 2008). Thus, if the uptake of mineral nutrients is improved by intercropping it may also affect the severity of diseases.

Multispecies cropping or intercropping, which may enable improved nutrient uptake and reduced disease development by the increased diversity of plant functional traits, is thereby a valuable cultivation technique, providing multiple ecosystem services and sustainable agriculture production systems. The aim of the present study was to investigate the effect of intercropping organically managed maize and faba beans to silage on the acquisition of mineral nutrients in shoots of both crops and on disease progression of leaf spots in faba beans. Our hypotheses were that intercropped maize and faba bean: i) increases the concentration and total uptake of mineral nutrients in plant shoots per land area, ii) reduces the severity of leaf spot diseases in faba bean compared with monocropped faba bean.

\section{Materials and methods}

\section{Field experiment sites and design}

Field experiments were established at three sites in south-east Sweden, in 2010 at Nöbbelöv (NL) and in 2011 at Helgegården ( $\mathrm{HG}$ ) and at Björkhaga ( $\mathrm{BH})($ Table 1). The field experiments were performed as on-farm trials by the Field Research Unit of the Swedish Rural Economy and Agricultural Societies (Hushållningssällskapet, Kristianstad). Composite top soil samples were taken and chemical parameters and soil texture were determined (Table 1).

The treatments of the present investigation formed part of a larger intercropping experiment where various amounts of $\mathrm{N}$ were applied as described by Stoltz and Nadeau (2014). Three out of the five treatments were used in the present investigation. An early hybrid (FAO 190) of maize cv. Isberi and cv. Aurora of faba bean were either cultivated in monocrop or intercropped. The three treatments were: 1 . monocropped maize (MM), 2. monocropped faba bean (MFB) and 3. intercropped maize and faba bean (IM and IFB) with four blocks (in total 12 plots in each experiment), laid out in a randomised complete block design. The treatments of the present investigation were called MFB 60N, MM 60N and Intercrop 60N as described in Stoltz and Nadeau (2014). Each plot consisted of four rows (each $12 \mathrm{~m}$ long and $0.75 \mathrm{~m}$ wide) of maize and thus the area of each plot was $36 \mathrm{~m}^{2}$. All treatments were fertilized with $60 \mathrm{~kg} \mathrm{~N} \mathrm{ha}^{-1}$ applied as cattle slurry. A nitrogen meter for manure (Agros Nova Mk3, Agros, Lidköping, Sweden) was used to determine the nitrogen content of the manure, and applied accordingly. Thereafter, samples of manure were taken and analysed for $\mathrm{NH}_{4}-\mathrm{N}$ according to Kjeldahl (KLK 65:1, Eurofins Food and Agri Sweden AB, Kristianstad). The nitrogen meter showed lower values than the values from the Kjeldahl analysis, thus the given amount of $\mathrm{N}$ in the treatments were higher than planned. The actual amounts of $\mathrm{N}$ per hectare were $69 \mathrm{~kg}$ at NL; $70 \mathrm{~kg}$ at $\mathrm{HG}$, and $86 \mathrm{~kg}$ at $\mathrm{BH}$.

Table 1. Sites and locations of field experiments, soil properties and dates of sowing

\begin{tabular}{|c|c|c|c|c|c|c|c|}
\hline \multicolumn{2}{|c|}{ Locations of field experiments } & \multicolumn{5}{|c|}{ Soil properties in topsoil (0-0.25 m) } & \multirow{2}{*}{$\begin{array}{c}\text { Sowing } \\
\text { date }\end{array}$} \\
\hline Name of site, year & $\begin{array}{l}\text { Longitude, } \\
\text { latitude }\end{array}$ & $\mathrm{pH}$ & $\begin{array}{c}\text { Organic } \\
\text { matter (\%) }\end{array}$ & $\begin{array}{c}\text { Clay content } \\
(\%)\end{array}$ & $\begin{array}{c}\mathrm{P}-\mathrm{AL} \\
\left(\mathrm{mg} \mathrm{kg}^{-1}\right)\end{array}$ & $\begin{array}{c}\mathrm{K}-\mathrm{AL} \\
\left(\mathrm{mg} \mathrm{kg}^{-1}\right)\end{array}$ & \\
\hline Nöbbelöv (NL), 2010 & $55^{\circ} 57^{\prime} \mathrm{N}, 14^{\circ} 2^{\prime} \mathrm{E}$ & 6.6 & 4.9 & 11 & 260 & 210 & 20 May \\
\hline Helgegården (HG), 2011 & $56^{\circ} 1^{\prime} \mathrm{N}, 14^{\circ} 4^{\prime} \mathrm{E}$ & 7.9 & 1.4 & 6 & 390 & 120 & 1 May \\
\hline Björkhaga (BH), 2011 & $56^{\circ} 4^{\prime} \mathrm{N}, 13^{\circ} 57^{\prime} \mathrm{E}$ & 7.1 & 3.1 & 6 & 200 & 250 & 1 May \\
\hline
\end{tabular}


The crops were sown in mid-May in 2010 and in early May in 2011 (Table 1). Row spacing in maize was $0.75 \mathrm{~m}$, seed rate was 85000 viable seeds $\mathrm{ha}^{-1}$ and sowing depth was $0.04-0.05 \mathrm{~m}$. Row spacing in faba bean was $0.12 \mathrm{~m}$, seed rate was 700000 viable seeds ha-1 and sowing depth was $0.05 \mathrm{~m}$. In the intercrop treatment, one row of legumes was sown between the maize rows and thus the row width was $0.375 \mathrm{~m}$. The seed rate in the intercrop was 85000 viable seeds $\mathrm{ha}^{-1}$ in maize and 350000 viable seeds ha ${ }^{-1}$ in faba bean. For all treatments, a four-row precision drill (Monosem, Edwardsville, KS, US) was used. Inter-row hoeing was only performed in the treatments with maize and not in the MFB treatments.

\section{Determination of leaf spots in faba bean}

Ten plants at maturity stage BBCH 78-80 in each plot were selected randomly for assessment of leaf spots on 1218 of August (Weber and Bleiholder 1990, Lancashire et al. 1991). The most common disease causing leaf spots in the investigated fields was chocolate spot disease (Botrytis fabae) identified by visual assessment, but spots of Ascochyta blight (Ascochyta fabae) were also visually identified. Thus, a mixture of the two pathogens causes the leaf spots and they are commonly present in Sweden (Akhter 2014). The plants were divided into three sections, the upper, middle and lower sections, which were similar in size. The leaf area infected with spots (\%) was estimated in the upper and in the middle part of the plants and sorted into eight classes accordingly; $0 \%$ infection $=$ Class $0,<1 \%=$ Class $1,1-5 \%=$ Class $2,6-10 \%=$ Class $3,11-25 \%=$ Class $4,26-50 \%=$ Class 5 and $>50 \%$ $=$ Class 6, dead plants = class 7. A DSI (Disease Severity Index) of the leaf spots was calculated using the formula:

$$
\mathrm{DSI}=\left(\left[0 \times \mathrm{X}_{0}\right]+\left[1 \times \mathrm{X}_{1}\right]+\left[3 \times \mathrm{X}_{2}\right]+\left[7.5 \times \mathrm{X}_{3}\right]+\left[18.5 \times \mathrm{X}_{4}\right]+\left[37.5 \times \mathrm{X}_{5}\right]+\left[75 \times \mathrm{X}_{6}\right]+\left[100 \times \mathrm{X}_{7}\right]\right) / \mathrm{N}
$$

where $X_{n}$ represents the number of plants in each class and $N$ is the number of investigated plants. Mean DSI of the upper and middle plant sections was calculated. There were no leaves in the lower section remaining on any of the plants, thus the lower section was not included in the calculations.

\section{Harvest}

The field trials were harvested on 27 September, 2010 and on 7-10 October, 2011. A $15 \mathrm{~m}^{2}$ area of maize was harvested in each plot of the intercrop and of the MM treatments using a single row maize chopper with scale wagon (JF MH 30, Denmark) at the early dent stage of maturity. The faba bean was harvested by hand at the maturity stage BBCH 97-99 (Weber and Bleiholder 1990, Lancashire et al. 1991) in a $4.5 \mathrm{~m}^{2}$ area in the intercrop treatment and in a $2 \mathrm{~m}^{2}$ area in the MFB treatment. All plants were cut at about $0.2 \mathrm{~m}$ above the ground and weighed on a field scale. Samples were taken to determine dry matter (DM) content.

\section{Determination of mineral nutrients}

At harvest, shoot samples were taken plot wise for determination of plant nutrient concentrations. The crops in the intercropped treatment were sampled separately. The minerals analysed were: nitrogen ( $N$ ) (according to Dumas), phosphorus (P), potassium (K), calcium (Ca), magnesium (Mg), manganese (Mn), copper (Cu), zinc ( $\mathrm{Zn})$, boron (B), iron (Fe), sodium (Na), sulphur (S) and aluminium (Al) (reference method NMKL 1611998 m, Eurofins Food \& Agro Sweden AB, Kristianstad, Sweden). Total mineral nutrient yield was calculated in the various cropping systems. The mineral nutrient land equivalent ratio (LER) was calculated as an indicator of the benefits of intercropping, according to:

$$
L E R_{x}=\frac{X Y_{i b b}}{X Y_{m b b}}+\frac{X Y_{\text {im }}}{X Y_{m m}}
$$

where $X$ is the specific nutrient. $X Y_{\text {ifb }}$ and $X Y_{m f b}$ are the specific nutrient yields per land area of IFB and MFB, respectively, and $X Y_{i m}$ and $X Y_{m m}$ are the mineral nutrient yields per land area of IM and $M M$.

\section{Statistical analyses}

Statistical analyses were performed with JMP 9.0 (SAS Institute 2010). A mixed linear model, adjusted with 'treatment', 'site' and the interaction 'treatment $\times$ site' as fixed factors and 'block (site)' as a random factor, was used. When the $F$-value was significant for the main effects and interactions of the fixed factors, pair-wise comparisons with Tukey's HSD-test were performed to identify significant differences $(p<0.050)$ among treatment means. The effect of intercropping for leaf spots was also analysed for each site separately. Relationships between shoot concentration of mineral nutrients and the disease severity index of leaf spots in faba beans, and between shoot concentrations of mineral nutrients and DM yield in the two crops, were analysed by simple linear regression. 


\section{Results \\ DM Yield}

Detailed results on DM yield were presented in Table 4 in Stoltz and Nadeau (2014). In short, the average DM yield of MFB for the three field experiments was $4263 \mathrm{~kg} \mathrm{ha}^{-1}$, which was significantly $(p<0.001)$ higher than of the IFB of $2381 \mathrm{~kg} \mathrm{ha}^{-1}$. Yield of IFB was 55, 39 and $75 \%$ of the MFB yield at the experimental sites NL, $\mathrm{HG}$ and BH, respectively. Average DM yield of MM in the three field experiments was $11296 \mathrm{~kg} \mathrm{ha}^{-1}$, which was significantly $(p<0.001)$ higher than the yield of IM of $7178 \mathrm{~kg} \mathrm{ha}^{-1}$. Yield of intercropped M was 59, 74 and $58 \%$ of the MM yield at $\mathrm{NL}, \mathrm{HG}$ and $\mathrm{BH}$ respectively.

\section{Disease severity index (DSI) of leaf spots in faba beans}

The DSI of leaf spots in FB was significantly lower in the IFB compared with MFB at BH and HG, at NL, the pattern was similar, but only tended to be significant ( $p=0.055)$ (Fig. 1). The mean DSI of leaf spots in the three experiments was significantly $(p<0.001)$ lower in IFB with an index of 25 than in MFB with an index of 45 (not shown). The average DSI of leaf spots of 56 at BH was significantly higher $(p<0.004)$ than at NL of 18 (not shown). At HG, the DSI of 29 did not differ from any of the other sites (not shown). There was no significant interaction between site and cropping treatment.

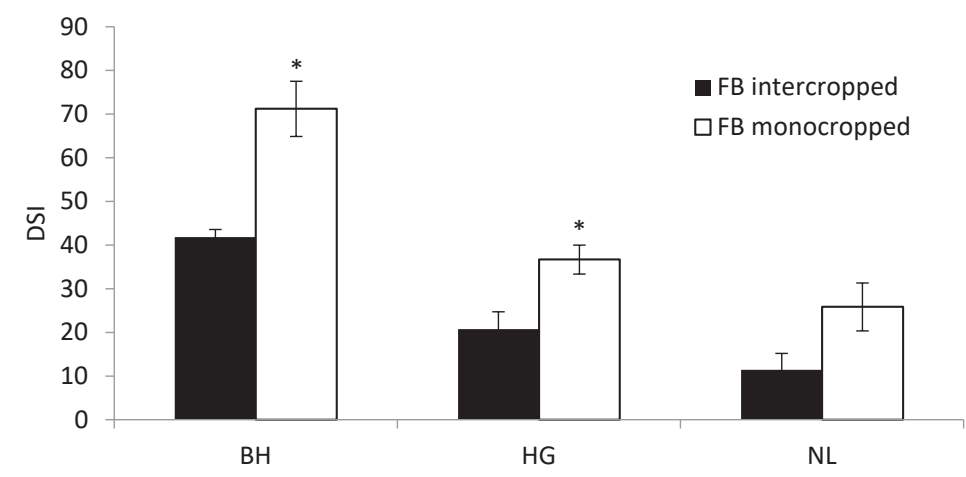

Fig. 1. Disease severity index (DSI) of leaf spots in monocropped (MFB) and intercropped faba bean (FB) in three field experiments, $n=4$. BH = Björkhaga, $H G=$ Helgegården and $\mathrm{NL}=$ Nöbbelöv. $*$ indicate significant differences between cropping treatments within sites, $p=0.004$ at $\mathrm{BH}, p=0.022$ at $\mathrm{HG}$ and $p=0.055$ at NL, Tukey's HSD test

\section{Concentrations of mineral nutrients in crop shoots}

\section{Faba bean}

Shoot concentrations of $\mathrm{K}, \mathrm{Ca}, \mathrm{Mg}$, Na and $\mathrm{S}$ were significantly higher in IFB compared with MFB, when averaged over sites (Table 2). There were significant interactions between cropping treatment and field experimental site for shoot concentrations of $\mathrm{K}, \mathrm{Ca}$ and $\mathrm{Mg}$ (Table 2). Concentration of $\mathrm{K}$ was higher in IFB than in MFB at HG, whereas concentrations of $\mathrm{Ca}$ and $\mathrm{Mg}$ were higher in IFB than in MFB at $\mathrm{BH}$. No effect of intercropping on concentration of macro nutrients was found at NL.

Mean concentrations of $\mathrm{N}$ and $\mathrm{P}$ in shoots of FB across the three experiments were $3.3 \%$ and $0.46 \%$ of DM, respectively, and no differences were found between the two cropping systems (not shown). There were significant differences in FB shoot concentrations of $\mathrm{N}$ between sites $(p<0.001)$; NL $(3.9 \%$ of DM) $>\mathrm{BH}(3.4 \%$ of DM) > HG $(2.7 \%$ of DM), and for P $(p=0.014)$; NL $(0.50 \%$ of $D M)=B H(0.48 \%$ of DM) $>$ HG $(0.40 \%$ of DM).

Shoot concentration of B was higher in IFB compared with MFB (Table 3) but no differences were found in shoot concentrations of $\mathrm{Mn}, \mathrm{Cu}, \mathrm{Zn}, \mathrm{Fe}$ and Mo between the two cropping systems, when averaged over sites. There were significant interactions between experimental site and cropping treatment for $\mathrm{Mn}$ and $\mathrm{Zn}$ but a difference between treatments was only shown for $\mathrm{Mn}$ with a higher concentration in IFB than in MFB at BH, whereas no differences between treatments were shown for Zn (Table 3). 
Table 2. Concentrations of macro nutrients in intercropped and monocropped faba bean in three field experiments

\begin{tabular}{|c|c|c|c|c|c|}
\hline \multirow{2}{*}{ Main effects or interaction } & K & $\mathrm{Ca}$ & $\mathrm{Mg}$ & $\mathrm{Na}$ & $S$ \\
\hline & \multicolumn{5}{|c|}{ (\% of DM) } \\
\hline \multicolumn{6}{|l|}{ Treatment, $\mathrm{n}=12$} \\
\hline MFB & $1.3^{\mathrm{b}}$ & $0.68^{b}$ & $0.14^{\mathrm{b}}$ & $0.05^{b}$ & $0.14^{b}$ \\
\hline IFB & $1.5^{\mathrm{a}}$ & $0.85^{\mathrm{a}}$ & $0.16^{\mathrm{a}}$ & $0.08^{\mathrm{a}}$ & $0.15^{\mathrm{a}}$ \\
\hline SEM & 0.03 & 0.04 & 0.0002 & 0.005 & 0.004 \\
\hline$p$ & $<0.001$ & $<0.001$ & $<0.001$ & $<0.001$ & 0.008 \\
\hline \multicolumn{6}{|l|}{ Site, $n=8$} \\
\hline $\mathrm{NL}$ & $1.4^{\mathrm{a}}$ & $0.88^{\mathrm{a}}$ & $0.16^{\mathrm{a}}$ & $0.10^{\mathrm{a}}$ & $0.17^{\mathrm{a}}$ \\
\hline HG & $1.5^{\mathrm{a}}$ & $0.57^{b}$ & $0.14^{\mathrm{b}}$ & $0.03^{b}$ & $0.11^{b}$ \\
\hline $\mathrm{BH}$ & $1.3^{\mathrm{a}}$ & $0.84^{\mathrm{a}}$ & $0.15^{\mathrm{a}}$ & $0.06^{b}$ & $0.15^{\mathrm{b}}$ \\
\hline SEM & 0.05 & 0.07 & 0.002 & 0.009 & 0.007 \\
\hline$p$ & 0.046 & 0.016 & $<0.001$ & 0.002 & $<0.001$ \\
\hline \multicolumn{6}{|l|}{ Treatment $\times$ site, $n=4$} \\
\hline \multicolumn{6}{|l|}{ NL } \\
\hline MFB & $1.3^{\mathrm{b}}$ & $0.85^{\mathrm{ab}}$ & $0.16^{\mathrm{ab}}$ & 0.08 & 0.17 \\
\hline IFB & $1.4^{\mathrm{b}}$ & $0.91^{\mathrm{ab}}$ & $0.16^{\mathrm{bc}}$ & 0.12 & 0.17 \\
\hline \multicolumn{6}{|l|}{ HG } \\
\hline MFB & $1.3^{\mathrm{b}}$ & $0.49^{c}$ & $0.13^{d}$ & 0.03 & 0.11 \\
\hline IFB & $1.8^{\mathrm{a}}$ & $0.65^{\mathrm{bc}}$ & $0.14^{\mathrm{cd}}$ & 0.04 & 0.11 \\
\hline \multicolumn{6}{|l|}{$\mathrm{BH}$} \\
\hline MFB & $1.3^{\mathrm{b}}$ & $0.69^{b c}$ & $0.14^{d}$ & 0.04 & 0.14 \\
\hline IFB & $1.4^{\mathrm{b}}$ & $0.99^{\mathrm{a}}$ & $0.17^{\mathrm{a}}$ & 0.07 & 0.16 \\
\hline SEM & 0.06 & 0.07 & 0.003 & 0.009 & 0.007 \\
\hline$p$ & 0.001 & 0.041 & $<0.001$ & ns & ns \\
\hline Common conc. FB ${ }^{1}$ & 1.2 & $0.2-0.4$ & 0.15 & $0.01-0.05$ & $0.26-0.45$ \\
\hline
\end{tabular}

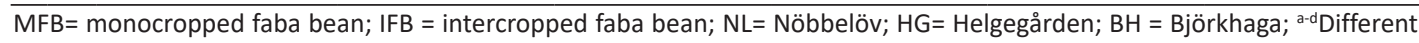
superscripts within columns indicate significant differences between cropping treatments, sites and their interaction $(p<0.05$, Tukey's HSD test); ${ }^{1}$ (from Blackwood 2007 and Spörndly 2003)

\section{Maize}

There were significant $(p<0.001)$ differences in maize shoot concentrations of $\mathrm{Mg}(\mathrm{NL}[0.14 \%$ of $\mathrm{DM}]>\mathrm{BH}$ and HG [0.11\% of DM]) between the sites but not of Na with an average of $0.15 \%$ (not shown). No differences were found in $\mathrm{Mg}$ and $\mathrm{Na}$ concentrations between the cropping treatments (not shown) or in $\mathrm{N}, \mathrm{P}, \mathrm{K}, \mathrm{Ca}, \mathrm{Mg}, \mathrm{Na}$, and $\mathrm{S}$ concentrations when averaged across sites (Table 4). There were significant interactions between site and cropping treatment in concentrations of $\mathrm{N}, \mathrm{P}, \mathrm{K}, \mathrm{Ca}$ and $\mathrm{S}$ shown in Table 4. At HG, the shoot concentrations of $\mathrm{N}$ and $\mathrm{S}$ were higher in IM than in MM while the opposite was found at $\mathrm{BH}$; at NL, no differences between the treatments were found. The shoot concentration of $\mathrm{P}$ was higher in IM than in $\mathrm{MM}$ at $\mathrm{NL}$ and $\mathrm{BH}$ while the opposite was found at HG. The shoot concentration of Ca was lower in IM than in MM at HG, and no differences in Ca concentrations were found between the cropping treatments at $\mathrm{NL}$ and $\mathrm{BH}$.

Average concentrations of $\mathrm{Cu}, \mathrm{Zn}$ and $\mathrm{Mo}$ in maize shoots were significantly higher in IM compared with $\mathrm{MM}$ (Table 5). For B, Mn and Fe, there were no significant differences in shoot concentrations between the cropping treatments. There was a significant interaction between cropping treatment and site for maize shoot concentration of $\mathrm{Mn}$ and $\mathrm{Mo}$ (Table 5). At BH, intercropping increased the shoot concentration of Mn whereas the opposite was found at HG, with lack of differences at NL. At HG intercropping increased the concentration of Mo whereas the opposite was found at $\mathrm{BH}$ with no difference between the cropping treatments at NL. 
Table 3. Concentrations of micro nutrients in intercropped and monocropped faba bean in three field experiments

\begin{tabular}{|c|c|c|c|c|c|c|}
\hline \multirow{2}{*}{ Main effects or interaction } & B & $\mathrm{Mn}$ & $\mathrm{Cu}$ & $\mathrm{Zn}$ & $\mathrm{Fe}$ & Mo \\
\hline & \multicolumn{6}{|c|}{$\left(\mathrm{mg} \mathrm{kg}^{-1} \mathrm{DM}\right)$} \\
\hline \multicolumn{7}{|l|}{ Treatment, $n=12$} \\
\hline MFB & $15.3^{b}$ & 21.3 & 10.0 & 36.5 & 169 & 3.9 \\
\hline IFB & $17.8^{\mathrm{a}}$ & 22.5 & 10.5 & 35.4 & 186 & 3.9 \\
\hline SEM & 0.44 & 0.51 & 0.35 & 1.33 & 13.2 & 0.18 \\
\hline $\mathrm{p}$ & 0.001 & ns & ns & ns & ns & ns \\
\hline \multicolumn{7}{|l|}{ Site, $n=8$} \\
\hline $\mathrm{NL}$ & $13.5^{b}$ & $20.6^{\mathrm{b}}$ & $11.4^{\mathrm{a}}$ & $42.0^{\mathrm{a}}$ & $105^{\mathrm{b}}$ & $1.5^{\mathrm{c}}$ \\
\hline HG & $17.1^{\mathrm{a}}$ & $19.6^{\mathrm{b}}$ & $10.6^{\mathrm{a}}$ & $33.4^{\mathrm{b}}$ & $195^{\mathrm{a}}$ & $6.3^{\mathrm{a}}$ \\
\hline $\mathrm{BH}$ & $19.0^{\mathrm{a}}$ & $25.4^{\mathrm{a}}$ & $8.9^{\mathrm{b}}$ & $32.5^{b}$ & $231^{a}$ & $3.9^{b}$ \\
\hline SEM & 0.63 & 0.62 & 0.43 & 2.15 & 18.2 & 0.26 \\
\hline$p$ & 0.001 & $<0.001$ & 0.002 & 0.022 & 0.002 & $<0.001$ \\
\hline \multicolumn{7}{|l|}{ Treament $\times$ site, $n=4$} \\
\hline \multicolumn{7}{|l|}{$\mathrm{NL}$} \\
\hline MFB & 13.0 & $21.8^{\mathrm{b}}$ & 11.5 & $43.8^{\mathrm{a}}$ & 98 & 1.5 \\
\hline IFB & 14.0 & $19.5^{\mathrm{b}}$ & 11.3 & $40.3^{\mathrm{ab}}$ & 113 & 1.6 \\
\hline \multicolumn{7}{|l|}{ HG } \\
\hline MFB & 15.3 & $19.3^{\mathrm{b}}$ & 10.3 & $34.8^{\mathrm{ab}}$ & 173 & 6.6 \\
\hline IFB & 19.3 & $20.0^{\mathrm{b}}$ & 10.9 & $32.0^{\mathrm{b}}$ & 218 & 6.0 \\
\hline \multicolumn{7}{|l|}{$\mathrm{BH}$} \\
\hline MFB & 17.8 & $22.8^{\mathrm{b}}$ & 8.3 & $31.0^{\mathrm{b}}$ & 235 & 3.6 \\
\hline IFB & 20.3 & $28.0^{\mathrm{a}}$ & 9.4 & $34.0^{\mathrm{ab}}$ & 228 & 4.2 \\
\hline SEM & 0.77 & 0.88 & 0.61 & 2.30 & 22.9 & 0.31 \\
\hline$p$ & ns & $<0.001$ & ns & 0.041 & ns & ns \\
\hline Common conc. FB ${ }^{1}$ & - & $24-33$ & $7.7-12$ & $36-46$ & $86-110$ & 0.5 \\
\hline
\end{tabular}

MFB= monocropped faba bean; IFB = intercropped faba bean; NL= Nöbbelöv; HG= Helgegården; BH = Björkhaga; ${ }^{a-b}$ Different superscripts within columns indicate significant differences between cropping treatments, sites and their interaction $\left(p<0.05\right.$, Tukey's HSD test); ${ }^{1}$ (from Blackwood 2007 and Spörndly 2003)

\section{Relationships between DM yield and mineral nutrient concentrations}

Relationships between DM yield and mineral nutrient concentration are shown in Table 6. The presence of significant relationships varied between sites. At NL, the only significant relationship between DM yield and mineral concentration was found for $\mathrm{N}$ in maize. No significant relationships were found for FB at NL. In maize at HG, significant negative relationships were found between DM yield and concentrations of N, S and Mo and significant positive relationships were found for $\mathrm{P}, \mathrm{Ca}$ and $\mathrm{Mn}$ concentrations. In FB, there were significant negative relationships between DM yield and concentrations of $\mathrm{K}, \mathrm{Ca}$ and $\mathrm{B}$ at $\mathrm{HG}$. At $\mathrm{BH}$, negative relationships were found between $\mathrm{DM}$ yield and concentrations of $\mathrm{P}, \mathrm{Ca}, \mathrm{Mg}$ and $\mathrm{Mn}$ in maize, whereas there were significant positive relationships between $\mathrm{DM}$ yield and concentrations of $\mathrm{N}, \mathrm{S}$ and Mo. In FB, there was a significant negative relationship between $\mathrm{DM}$ yield and $\mathrm{Ca}$ concentration at $\mathrm{BH}$. Averaged over all sites, significant negative relationships occurred between $\mathrm{DM}$ yield and concentrations of $\mathrm{Ca}, \mathrm{Mg}, \mathrm{B}, \mathrm{Mn}$ and $\mathrm{Zn}$ in maize. In FB, there were significant negative relationships between $\mathrm{DM}$ yield and concentrations of $\mathrm{K}, \mathrm{Ca}, \mathrm{Mg}, \mathrm{Na}$ and $\mathrm{S}$, whereas $\mathrm{DM}$ yield was significantly positively related the Mo concentration, when averaged across sites. 
Table 4. Concentrations of macro nutrients in intercropped and monocropped maize in three field experiments

\begin{tabular}{|c|c|c|c|c|c|}
\hline \multirow{2}{*}{ Main effects or interaction } & $\mathrm{N}$ & $P$ & K & $\mathrm{Ca}$ & $S$ \\
\hline & \multicolumn{5}{|c|}{ (\% of DM) } \\
\hline \multicolumn{6}{|l|}{ Treatment, $\mathrm{n}=12$} \\
\hline MM & 0.99 & 0.26 & 0.81 & 0.21 & 0.081 \\
\hline IM & 1.0 & 0.27 & 0.84 & 0.23 & 0.083 \\
\hline SEM & 0.015 & 0.0052 & 0.025 & 0.015 & 0.0017 \\
\hline$p$ & ns & ns & ns & ns & ns \\
\hline \multicolumn{6}{|l|}{ Site, $n=8$} \\
\hline $\mathrm{NL}$ & 1.0 & $0.24^{\mathrm{b}}$ & 0.84 & $0.30^{\mathrm{a}}$ & $0.084^{a}$ \\
\hline HG & 1.0 & $0.28^{\mathrm{a}}$ & 0.84 & $0.19^{b}$ & $0.086^{\mathrm{a}}$ \\
\hline $\mathrm{BH}$ & 1.0 & $0.28^{\mathrm{a}}$ & 0.80 & $0.19^{b}$ & $0.076^{\mathrm{b}}$ \\
\hline SEM & 0.023 & 0.0063 & 0.030 & 0.0189 & 0.0017 \\
\hline$p$ & ns & $<0.001$ & ns & $<0.001$ & 0.002 \\
\hline \multicolumn{6}{|l|}{ Treatment $\times$ site, $\mathrm{n}=4$} \\
\hline \multicolumn{6}{|l|}{$\mathrm{NL}$} \\
\hline $\mathrm{MM}$ & $1.0^{\mathrm{ab}}$ & $0.22^{\mathrm{d}}$ & $0.76^{\mathrm{a}}$ & $0.27^{\mathrm{a}}$ & $0.080^{\mathrm{bc}}$ \\
\hline IM & $1.1^{\mathrm{a}}$ & $0.26^{\mathrm{bc}}$ & $0.92^{\mathrm{a}}$ & $0.32^{\mathrm{a}}$ & $0.087^{\mathrm{ab}}$ \\
\hline \multicolumn{6}{|l|}{ HG } \\
\hline MM & $0.9^{b}$ & $0.31^{\mathrm{a}}$ & $0.83^{a}$ & $0.25^{\mathrm{ab}}$ & $0.080^{b c}$ \\
\hline IM & $1.1^{\mathrm{a}}$ & $0.25^{\text {cd }}$ & $0.86^{\mathrm{a}}$ & $0.13^{c}$ & $0.093^{a}$ \\
\hline \multicolumn{6}{|l|}{$\mathrm{BH}$} \\
\hline MM & $1.1^{\mathrm{a}}$ & $0.26^{c d}$ & $0.84^{\mathrm{a}}$ & $0.13^{\mathrm{bc}}$ & $0.083^{\mathrm{ab}}$ \\
\hline IM & $0.9^{b}$ & $0.30^{\mathrm{ab}}$ & $0.76^{\mathrm{a}}$ & $0.25^{\mathrm{ab}}$ & $0.070^{c}$ \\
\hline SEM & 0.026 & 0.0090 & 0.043 & 0.027 & 0.0024 \\
\hline$p$ & $<0.001$ & $<0.001$ & 0.038 & 0.001 & $<0.001$ \\
\hline Common conc. $\mathrm{M}^{1}$ & - & 0.23 & 1.1 & 0.24 & 0.39 \\
\hline
\end{tabular}

\section{Leaf spots and mineral nutrients}

A significant negative linear relationship $(r=-0.69, p<0.001)$ between $\mathrm{Cu}$ shoot concentration and leaf spot DSI was found in FB (Fig. 2). Significant negative relationships between leaf spot DSI and shoot concentrations of $K$ $(r=-0.44, p=0.033)$ and $\mathrm{Fe}(r=-0.46, p=0.025)$ were found. No other significant linear relationships were found between leaf spot DSI and concentrations of mineral nutrients in shoots.

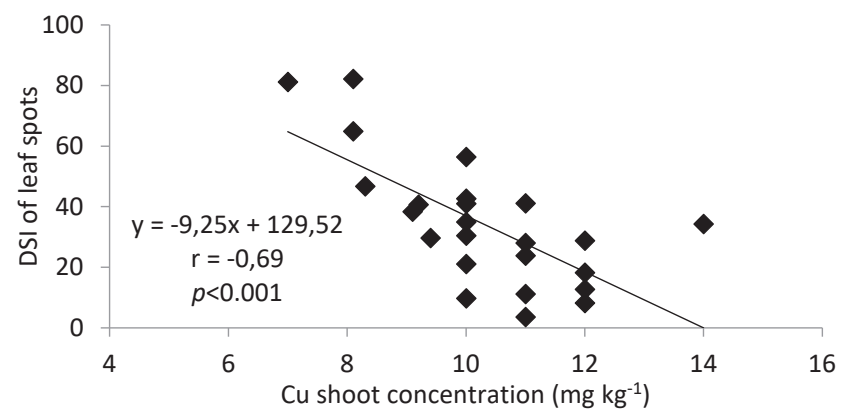

Fig. 2. Relationship between disease severity index (DSI) of leaf spots and $\mathrm{Cu}$ shoot concentrations of faba bean in three field experiments, $\mathrm{n}=24$ 
Table 5. Concentrations of micro nutrients in intercropped and monocropped maize in three field experiments

\begin{tabular}{|c|c|c|c|c|c|c|}
\hline \multirow{2}{*}{ Main effects or interaction } & B & $\mathrm{Mn}$ & $\mathrm{Cu}$ & $\mathrm{Zn}$ & $\mathrm{Fe}$ & Mo \\
\hline & \multicolumn{6}{|c|}{ (mg kg-1 DM) } \\
\hline \multicolumn{7}{|l|}{ Treatment, $\mathrm{n}=12$} \\
\hline $\mathrm{MM}$ & 4.6 & 7.9 & $4.1^{b}$ & $17.2^{\mathrm{b}}$ & 129 & $1.8^{\mathrm{b}}$ \\
\hline IM & 4.5 & 8.3 & $4.6^{\mathrm{a}}$ & $20.8^{\mathrm{a}}$ & 148 & $2.1^{\mathrm{a}}$ \\
\hline SEM & 0.21 & 0.31 & 0.11 & 0.75 & 9.8 & 0.10 \\
\hline $\mathrm{p}$ & ns & ns & 0.004 & 0.003 & ns & 0.049 \\
\hline
\end{tabular}

Site, $\mathrm{n}=8$

$\begin{array}{lcccccc}\mathrm{NL} & 5.2^{\mathrm{a}} & 9.2^{\mathrm{a}} & 4.3 & 22.5^{\mathrm{a}} & 76^{\mathrm{b}} & 1.1^{\mathrm{b}} \\ \mathrm{HG} & 4.2^{\mathrm{b}} & 7.8^{\mathrm{b}} & 4.5 & 18.3^{\mathrm{b}} & 185^{\mathrm{a}} & 2.6^{\mathrm{a}} \\ \mathrm{BH} & 4.2^{\mathrm{b}} & 7.4^{\mathrm{b}} & 4.3 & 16.3^{\mathrm{b}} & 155^{\mathrm{a}} & 2.1^{\mathrm{a}} \\ \mathrm{SEM} & 0.25 & 0.38 & 0.13 & 0.92 & 12 & 0.14 \\ p & 0.015 & 0.009 & \mathrm{~ns} & <0.001 & <0.001 & <0.001\end{array}$

Treatment $\times$ site, $\mathrm{n}=4$

$\mathrm{NL}$

$\begin{array}{lllllll}\text { MM } & 5.0 & 8.9^{\mathrm{a}} & 4.2 & 20.3 & 62 & 1.0^{\mathrm{c}} \\ \text { IM } & 5.5 & 9.4^{\mathrm{a}} & 4.4 & 24.8 & 89 & 1.1^{\mathrm{c}}\end{array}$

HG

MM

IM

$\mathrm{BH}$

MM

IM

SEM

$p$

Common conc. $\mathrm{M}^{1}$

conc. $\mathrm{M}^{1}$

columns indicate significant differences between cropping treatments, sites and their interaction $\left(p<0\right.$; 05 , Tukey's $\mathrm{HSD}$ test): ${ }^{1}$ (from Blackwood 2007 and Spörndly 2003)

Table 6. Relationships ( $r$-values) between concentrations of mineral nutrients and yields (kg dry matter) of maize (M) and faba bean (FB)

\begin{tabular}{|c|c|c|c|c|c|c|c|c|c|c|c|c|c|c|c|c|}
\hline \multirow{3}{*}{$\begin{array}{l}\text { Mineral } \\
\text { nutrient }\end{array}$} & \multicolumn{4}{|c|}{$\mathrm{NL}, \mathrm{n}=8$} & \multicolumn{4}{|c|}{$\mathrm{HG}, \mathrm{n}=8$} & \multicolumn{4}{|c|}{$\mathrm{BH}, \mathrm{n}=8$} & \multicolumn{4}{|c|}{$\begin{array}{l}\text { Average of three sites, } \\
\qquad n=24\end{array}$} \\
\hline & \multicolumn{2}{|c|}{$M$} & \multicolumn{2}{|c|}{ FB } & \multicolumn{2}{|c|}{ M } & \multicolumn{2}{|c|}{ FB } & \multicolumn{2}{|c|}{$M$} & \multicolumn{2}{|c|}{ FB } & \multicolumn{2}{|c|}{$M$} & \multicolumn{2}{|c|}{ FB } \\
\hline & $r$ & $p$ & $r$ & $p$ & $r$ & $p$ & $r$ & $p$ & $r$ & $p$ & $r$ & $p$ & $r$ & $p$ & $r$ & $p$ \\
\hline $\mathrm{N}$ & -0.72 & 0.04 & 0.42 & ns & -0.80 & 0.017 & 0.41 & ns & 0.78 & 0.023 & 0.24 & ns & -0.14 & ns & -0.32 & ns \\
\hline$P$ & -0.54 & ns & 0.17 & ns & 0.78 & 0.022 & 0.56 & ns & -0.84 & 0.009 & -0.20 & ns & 0.20 & ns & -0.10 & ns \\
\hline K & -0.39 & ns & -0.14 & ns & -0.52 & ns & -0.87 & 0.006 & 0.61 & ns & -0.17 & ns & -0.14 & ns & -0.41 & 0.043 \\
\hline $\mathrm{Ca}$ & -0.26 & ns & -0.54 & ns & 0.81 & 0.015 & -0.85 & 0.007 & -0.89 & 0.003 & -0.76 & 0.028 & -0.57 & 0.004 & -0.57 & 0.004 \\
\hline $\mathrm{Mg}$ & 0.14 & ns & 0.37 & ns & 0.32 & ns & -0.61 & ns & -0.76 & 0.029 & -0.65 & ns & -0.62 & 0.001 & -0.46 & 0.024 \\
\hline $\mathrm{Na}$ & 0.00 & ns & -0.39 & ns & 0.00 & ns & -0.57 & ns & 0.24 & ns & 0.67 & ns & 0.30 & ns & -0.61 & 0.002 \\
\hline$S$ & -0.32 & ns & -0.26 & ns & -0.71 & 0.046 & 0.00 & ns & 0.75 & 0.035 & 0.26 & ns & -0.14 & ns & -0.42 & 0.036 \\
\hline B & -0.30 & ns & -0.17 & ns & 0.51 & ns & -0.82 & 0.011 & -0.22 & ns & -0.66 & ns & -0.41 & 0.046 & -0.10 & ns \\
\hline $\mathrm{Mn}$ & -0.17 & ns & 0.44 & ns & 0.84 & 0.009 & 0.28 & ns & -0.93 & $<0.001$ & -0.66 & ns & -0.48 & 0.019 & -0.10 & ns \\
\hline $\mathrm{Cu}$ & -0.36 & ns & 0.20 & ns & -0.61 & ns & -0.26 & ns & -0.71 & ns & 0.14 & ns & -0.35 & ns & -0.28 & ns \\
\hline $\mathrm{Zn}$ & -0.44 & ns & 0.52 & ns & -0.66 & ns & -0.26 & ns & -0.20 & ns & -0.26 & ns & -0.64 & $<0.001$ & -0.22 & ns \\
\hline $\mathrm{Fe}$ & -0.39 & ns & -0.52 & ns & 0.32 & ns & -0.47 & ns & -0.56 & ns & 0.10 & ns & 0.37 & ns & 0.24 & ns \\
\hline Mo & -0.10 & ns & -0.24 & ns & -0.91 & 0.002 & 0.58 & ns & 0.77 & 0.025 & 0.00 & ns & 0.40 & ns & 0.55 & 0.006 \\
\hline
\end{tabular}




\section{Yield of mineral nutrients}

The average total yields (mineral nutrient concentration $\times \mathrm{DM}$ yield) of $\mathrm{Ca}, \mathrm{Na}, \mathrm{Mn}, \mathrm{Cu}$ and $\mathrm{Zn}$ across the three sites were highest in the intercrop treatment (Tables 7 and 8). For the other investigated nutrients, the intercrop treatment was not significantly different from any of the monocrop treatments. Significant interactions between cropping treatment and site were found for all minerals shown in Tables 7 and 8.

At $\mathrm{BH}$, the IM/FB treatment had higher yields of $\mathrm{N}, \mathrm{Ca}, \mathrm{Na}, \mathrm{Mn}$ and $\mathrm{B}$ than the monocrops. Fewer significant differences were found between IM/FB and the other treatments at the other sites; At HG, the Zn yield were highest in the IM/FB treatment. The IM/FB treatments had higher $\mathrm{K}$ yield compared with MFB, and higher $\mathrm{Cu}$ and Mo yields than MM. At NL, the IM/FB treatment had higher $\mathrm{K}$ and Mg yields than MFB. The IM/FB treatment had never significantly lower yields than the other treatments for any of the minerals.

Table 7. Yield of macro nutrients in monocropped and intercropped maize and faba bean in three field experiments

\begin{tabular}{|c|c|c|c|c|c|c|c|}
\hline \multirow{2}{*}{ Main effects or interaction } & $\mathrm{N}$ & $\mathrm{P}$ & K & $\mathrm{Ca}$ & $\mathrm{Mg}$ & $\mathrm{Na}$ & $\mathrm{S}$ \\
\hline & \multicolumn{7}{|c|}{$\left(\mathrm{kg} \mathrm{ha}^{-1}\right)$} \\
\hline \multicolumn{8}{|l|}{ Treatment, $\mathrm{n}=12$} \\
\hline MM & $112.8^{\mathrm{b}}$ & $29.9^{a}$ & $92.1^{\mathrm{a}}$ & $22.3^{c}$ & $12.8^{\mathrm{a}}$ & $1.76^{\mathrm{b}}$ & $9.15^{\mathrm{a}}$ \\
\hline MFB & $138.5^{a}$ & $19.4^{\mathrm{b}}$ & $54.2^{\mathrm{b}}$ & $27.0^{\mathrm{b}}$ & $6.0^{\mathrm{b}}$ & $1.77^{\mathrm{b}}$ & $5.56^{\mathrm{b}}$ \\
\hline $\mathrm{IM} / \mathrm{FB}$ & $149.6^{\mathrm{a}}$ & $30.2^{\mathrm{a}}$ & $95.3^{\mathrm{a}}$ & $35.9^{a}$ & $12.0^{\mathrm{a}}$ & $2.80^{\mathrm{a}}$ & $9.36^{\mathrm{a}}$ \\
\hline SEM & 5.76 & 1.17 & 3.31 & 1.3 & 0.41 & 0.13 & 0.35 \\
\hline$p$ & $<0.001$ & $<0.001$ & $<0.001$ & $<0.001$ & $<0.001$ & $<0.001$ & $<0.001$ \\
\hline \multicolumn{8}{|l|}{ Site, $n=12$} \\
\hline $\mathrm{NL}$ & $93.8^{\mathrm{c}}$ & $15.8^{\mathrm{b}}$ & $50.2^{\mathrm{b}}$ & $23.0^{\mathrm{b}}$ & $7.36^{\mathrm{b}}$ & $1.86^{\mathrm{b}}$ & $5.49^{b}$ \\
\hline HG & $133.6^{\mathrm{b}}$ & $29.1^{\mathrm{a}}$ & $91.4^{\mathrm{a}}$ & $26.4^{\mathrm{b}}$ & $10.7^{\mathrm{a}}$ & $1.77^{\mathrm{b}}$ & $8.44^{\mathrm{a}}$ \\
\hline $\mathrm{BH}$ & $173.4^{\mathrm{a}}$ & $34.5^{\mathrm{a}}$ & $100.0^{\mathrm{a}}$ & $35.8^{\mathrm{a}}$ & $12.7^{\mathrm{a}}$ & $2.70^{\mathrm{a}}$ & $10.14^{\mathrm{a}}$ \\
\hline SEM & 8.07 & 1.64 & 4.36 & 1.3 & 0.56 & 0.14 & 0.49 \\
\hline$p$ & $<0.001$ & $<0.001$ & $<0.001$ & $<0.001$ & $<0.001$ & 0.002 & $<0.001$ \\
\hline \multicolumn{8}{|l|}{ Treatment $\times$ site, $n=4$} \\
\hline \multicolumn{8}{|l|}{ NL } \\
\hline MM & $72.7^{\mathrm{e}}$ & $15.7^{d}$ & $55.2^{\text {cd }}$ & $19.1^{c}$ & $9.8^{\mathrm{bc}}$ & $1.10^{\mathrm{c}}$ & $5.86^{d}$ \\
\hline MFB & $108.5^{c d}$ & $13.5^{\mathrm{d}}$ & $36.0^{d}$ & $22.8^{\mathrm{bc}}$ & $4.3^{\mathrm{d}}$ & $2.14^{\mathrm{bc}}$ & $4.40^{d}$ \\
\hline $\mathrm{IM} / \mathrm{FB}$ & $100.2^{\text {cde }}$ & $18.3^{d}$ & 59.5 & $27.1^{\mathrm{bc}}$ & 8.0 & $2.34^{\mathrm{b}}$ & $6.22^{d}$ \\
\hline \multicolumn{8}{|l|}{ HG } \\
\hline $\mathrm{MM}$ & $103.9^{\mathrm{de}}$ & $35.7^{\mathrm{ab}}$ & $95.0^{\mathrm{b}}$ & $28.2^{\mathrm{bc}}$ & $13.0^{\mathrm{ab}}$ & $1.73^{\mathrm{bc}}$ & $9.23^{\mathrm{ab}}$ \\
\hline MFB & $149.2^{\mathrm{bc}}$ & $22.8^{\mathrm{cd}}$ & $68.0^{c}$ & $26.5^{\mathrm{bc}}$ & $7.2^{\mathrm{cd}}$ & $1.38^{\mathrm{bc}}$ & $5.83^{d}$ \\
\hline $\mathrm{IM} / \mathrm{FB}$ & $147.9^{b c}$ & $28.9^{\mathrm{bc}}$ & $111.2^{\mathrm{ab}}$ & $24.4^{\mathrm{bc}}$ & $12.0^{\mathrm{b}}$ & $2.19^{\mathrm{b}}$ & $10.27^{\mathrm{ab}}$ \\
\hline \multicolumn{8}{|l|}{$\mathrm{BH}$} \\
\hline $\mathrm{MM}$ & $161.7^{\mathrm{b}}$ & $38.3^{\mathrm{ab}}$ & $126.0^{\mathrm{a}}$ & $19.5^{c}$ & $15.8^{\mathrm{a}}$ & $2.44^{\mathrm{b}}$ & $12.36^{\mathrm{a}}$ \\
\hline MFB & $157.9^{\mathrm{b}}$ & $21.9^{\text {cd }}$ & $58.6^{c d}$ & $31.7^{b}$ & $6.4^{\mathrm{cd}}$ & $1.81^{\mathrm{bc}}$ & $6.45^{\mathrm{cd}}$ \\
\hline $\mathrm{IM} / \mathrm{FB}$ & $200.5^{a}$ & $43.3^{\mathrm{a}}$ & $115.2^{\mathrm{ab}}$ & $56.1^{\mathrm{a}}$ & $16.0^{\mathrm{a}}$ & $3.86^{\mathrm{a}}$ & $11.60^{\mathrm{ab}}$ \\
\hline SEM & 9.97 & 2.02 & 5.73 & 2.25 & 0.72 & 0.23 & 0.6 \\
\hline$p$ & 0.008 & $<0.001$ & $<0.001$ & $<0.001$ & $<0.001$ & 0.001 & $<0.001$ \\
\hline
\end{tabular}

$\mathrm{MM}$ = monocropped maize; MFB = monocropped faba bean; IM/FB = Intercropped maize/faba bean; NL = Nöbbelöv; $\mathrm{HG}=\mathrm{Helgegården;} \mathrm{BH}$ = Björkhaga; ${ }^{\text {a-d } D i f f e r e n t ~ s u p e r s c r i p t s ~ w i t h i n ~ c o l u m n s ~ i n d i c a t e ~ s i g n i f i c a n t ~ d i f f e r e n c e s ~ b e t w e e n ~ c r o p p i n g ~ t r e a t m e n t s, ~ s i t e s ~ a n d ~ t h e i r ~ i n t e r a c t i o n ~}$ $(p<0.05$, Tukey's HSD test) 
Table 8. Yield of micro nutrients in monocropped and intercropped maize and faba bean in three field experiments

\begin{tabular}{|c|c|c|c|c|c|c|}
\hline \multirow{2}{*}{ Main effects or interaction } & $\mathrm{Mn}$ & $\mathrm{Cu}$ & $\mathrm{Zn}$ & B & $\mathrm{Fe}$ & Mo \\
\hline & \multicolumn{6}{|c|}{$\left(\mathrm{g} \mathrm{ha}^{-1}\right)$} \\
\hline \multicolumn{7}{|l|}{ Treatment, $n=12$} \\
\hline $\mathrm{MM}$ & $84.2^{\mathrm{b}}$ & $46.2^{b}$ & $187.1^{\mathrm{b}}$ & $50.9^{b}$ & $1559^{\mathrm{a}}$ & $22.3^{\mathrm{ab}}$ \\
\hline MFB & $89.4^{\mathrm{b}}$ & $42.2^{\mathrm{b}}$ & $150.6^{c}$ & $66.6^{\mathrm{a}}$ & $759^{b}$ & $19.0^{\mathrm{b}}$ \\
\hline $\mathrm{I} M / \mathrm{FB}$ & $114.6^{\mathrm{a}}$ & $57.5^{\mathrm{a}}$ & $228.0^{\mathrm{a}}$ & $74.9^{\mathrm{a}}$ & $1623^{a}$ & $25.9^{\mathrm{a}}$ \\
\hline SEM & 3.64 & 2.42 & 9.8 & 2.75 & 101 & 1.4 \\
\hline$p$ & $<0.001$ & $<0.001$ & $<0.001$ & $<0.001$ & $<0.001$ & 0.007 \\
\hline \multicolumn{7}{|l|}{ Site, $n=12$} \\
\hline $\mathrm{NL}$ & $64.2^{c}$ & $32.2^{\mathrm{b}}$ & $143.9^{b}$ & $38.5^{\mathrm{c}}$ & $419^{b}$ & $6.1^{\mathrm{b}}$ \\
\hline HG & $103.1^{\mathrm{b}}$ & $56.1^{\mathrm{a}}$ & $205.0^{\mathrm{a}}$ & $70.0^{\mathrm{b}}$ & $1709^{a}$ & $32.5^{\mathrm{a}}$ \\
\hline $\mathrm{BH}$ & $120.9^{\mathrm{a}}$ & $57.6^{\mathrm{a}}$ & $216.8^{\mathrm{a}}$ & $83.9^{\mathrm{a}}$ & $1814^{\mathrm{a}}$ & $28.5^{\mathrm{a}}$ \\
\hline SEM & 4.24 & 3.04 & 13.3 & 3.38 & 101 & 1.4 \\
\hline$p$ & $<0.001$ & $<0.001$ & 0.008 & $<0.001$ & $<0.001$ & $<0.001$ \\
\hline \multicolumn{7}{|l|}{ Treatment $\times$ site, $n=4$} \\
\hline \multicolumn{7}{|l|}{$\mathrm{NL}$} \\
\hline MM & $64.8^{\mathrm{cd}}$ & $30.3^{d}$ & $144.7^{d}$ & $35.9^{e}$ & $446^{b c}$ & $7.3^{\mathrm{de}}$ \\
\hline MFB & $58.2^{d}$ & $31.0^{\mathrm{d}}$ & $118.0^{d}$ & $35.0^{\mathrm{e}}$ & $263^{c}$ & $3.9^{\mathrm{e}}$ \\
\hline $\mathrm{IM} / \mathrm{FB}$ & $69.4^{c d}$ & $35.3^{d}$ & $169.1^{c d}$ & $44.7^{\mathrm{de}}$ & $548^{\mathrm{bc}}$ & $7.0^{\mathrm{de}}$ \\
\hline \multicolumn{7}{|l|}{$H G$} \\
\hline MM & $114.0^{\mathrm{b}}$ & $48.4^{b c d}$ & $173.3^{\mathrm{cd}}$ & $54.4^{\text {cde }}$ & $2193^{a}$ & $17.8^{\mathrm{cd}}$ \\
\hline MFB & $104.5^{\mathrm{b}}$ & $55.8^{\mathrm{abc}}$ & $188.6^{\mathrm{bcd}}$ & $83.1^{\mathrm{b}}$ & $919^{b c}$ & $36.1^{\mathrm{ab}}$ \\
\hline $\mathrm{IM} / \mathrm{FB}$ & $90.9^{b c}$ & $64.1^{\mathrm{ab}}$ & $253.3^{\mathrm{a}}$ & $72.4^{b c}$ & $2015^{a}$ & $43.7^{\mathrm{a}}$ \\
\hline \multicolumn{7}{|l|}{$\mathrm{BH}$} \\
\hline MM & $73.8^{c d}$ & $59.9^{\mathrm{ab}}$ & $243.4^{\mathrm{abc}}$ & $62.3^{\mathrm{bcd}}$ & $2037^{a}$ & $41.7^{\mathrm{a}}$ \\
\hline MFB & $105.4^{b}$ & $39.6^{\mathrm{cd}}$ & $145.2^{\mathrm{d}}$ & $81.7^{b}$ & $1096^{b}$ & $17.0^{\mathrm{cd}}$ \\
\hline $\mathrm{IM} / \mathrm{FB}$ & $183.5^{\mathrm{a}}$ & $73.3^{\mathrm{a}}$ & $261.8^{\mathrm{ab}}$ & $107.7^{\mathrm{a}}$ & $2307^{a}$ & $26.9^{b c}$ \\
\hline SEM & 6.3 & 4.2 & 17 & 4.76 & 175 & 2.42 \\
\hline$p$ & $<0.001$ & 0.002 & 0.004 & $<0.001$ & 0.023 & $<0.001$ \\
\hline
\end{tabular}

\section{Land equivalent ratio of mineral nutrients}

The mineral nutrient LER of intercropped faba bean and maize together with their total LER are shown in Table 9. The partial LER of faba bean was $>0.5$ for all minerals except for $\mathrm{Mn}$ at NL, and for N, P, Mg, S, Mn, Cu, Zn, B and Mo at HG. In maize, partial LER was $>0.5$ for all minerals except for $\mathrm{Ca}$ and $\mathrm{Mn}$ at $\mathrm{HG}$ and for $\mathrm{N}$ and $\mathrm{Mo}$ at BH. Maize LER was highest for $\mathrm{N}$ and $\mathrm{S}$ at $\mathrm{HG}$, and for $\mathrm{Mn}$ at BH. Total mineral nutrient LER was $>1$ in all minerals except for $\mathrm{P}, \mathrm{Ca}$ and $\mathrm{Mn}$ at $\mathrm{HG}$. 
Table 9. Land equivalent ratio (LER) of intercropped faba bean and maize and their total LER of mineral nutrients in three field experiments, $\mathrm{n}=4$

\begin{tabular}{|c|c|c|c|c|c|c|c|c|c|c|c|c|c|}
\hline & $\mathrm{N}$ & $\mathrm{P}$ & $\mathrm{K}$ & $\mathrm{Ca}$ & $\mathrm{Mg}$ & $\mathrm{Na}$ & S & $\mathrm{Mn}$ & $\mathrm{Cu}$ & $\mathrm{Zn}$ & B & $\mathrm{Fe}$ & Mo \\
\hline \multicolumn{14}{|c|}{ FB nutrient LER } \\
\hline $\mathrm{NL}$ & $0.51^{b}$ & $0.54^{\mathrm{b}}$ & $0.58^{b}$ & $0.61^{b}$ & $0.53^{b}$ & $0.80^{\mathrm{ab}}$ & $0.57^{b}$ & $0.49^{b}$ & $0.54^{\mathrm{b}}$ & $0.51^{\mathrm{b}}$ & $0.60^{\mathrm{ab}}$ & 0.66 & $0.61^{\mathrm{ab}}$ \\
\hline HG & $0.37^{\mathrm{b}}$ & $0.35^{\mathrm{b}}$ & $0.56^{\mathrm{b}}$ & $0.52^{\mathrm{b}}$ & $0.42^{\mathrm{b}}$ & $0.72^{\mathrm{b}}$ & $0.40^{\mathrm{b}}$ & $0.40^{\mathrm{b}}$ & $0.41^{b}$ & $0.36^{\mathrm{b}}$ & $0.49^{b}$ & 0.52 & $0.36^{\mathrm{b}}$ \\
\hline $\mathrm{BH}$ & $0.79^{\mathrm{a}}$ & $0.82^{\mathrm{a}}$ & $0.87^{\mathrm{a}}$ & $1.10^{\mathrm{a}}$ & $0.96^{\mathrm{a}}$ & $1.40^{\mathrm{a}}$ & $0.88^{\mathrm{a}}$ & $0.95^{\mathrm{a}}$ & $0.90^{\mathrm{a}}$ & $0.85^{\mathrm{a}}$ & $0.88^{\mathrm{a}}$ & 0.76 & $0.90^{\mathrm{a}}$ \\
\hline$p$ & 0.001 & 0.001 & 0.009 & $<0.001$ & $<0.001$ & 0.028 & 0.001 & $<0.001$ & 0.009 & $<0.001$ & 0.010 & ns & 0.024 \\
\hline \multicolumn{14}{|c|}{ M nutrient LER } \\
\hline NL & $0.61^{\mathrm{b}}$ & 0.69 & 0.67 & $0.70^{\mathrm{ab}}$ & 0.56 & 0.57 & $0.62^{\mathrm{b}}$ & $0.59^{b}$ & 0.61 & 0.71 & 0.62 & 0.80 & $0.60^{\mathrm{b}}$ \\
\hline HG & $0.88^{\mathrm{a}}$ & 0.59 & 0.77 & $0.38^{\mathrm{b}}$ & 0.69 & 0.74 & $0.86^{\mathrm{a}}$ & $0.43^{b}$ & 0.86 & 1.05 & 0.59 & 0.72 & $1.80^{\mathrm{a}}$ \\
\hline $\mathrm{BH}$ & $0.50^{\mathrm{b}}$ & 0.68 & 0.52 & $1.10^{\mathrm{a}}$ & 0.64 & 0.55 & $0.49^{b}$ & $1.2^{\mathrm{a}}$ & 0.68 & 0.58 & 0.58 & 0.77 & $0.30^{c}$ \\
\hline$p$ & 0.002 & ns & ns & 0.015 & ns & 0.050 & 0.003 & $<0.001$ & ns & ns & ns & ns & $<0.001$ \\
\hline \multicolumn{14}{|c|}{ Total nutrient LER } \\
\hline $\mathrm{NL}$ & 1.12 & $1.25^{\mathrm{ab}}$ & 1.25 & $1.31^{\mathrm{b}}$ & $1.09^{b}$ & 1.37 & 1.19 & $1.08^{\mathrm{b}}$ & $1.15^{\mathrm{b}}$ & 1.22 & 1.220 & 1.46 & $1.21^{\mathrm{b}}$ \\
\hline HG & 1.25 & $0.94^{\mathrm{b}}$ & 1.33 & $0.90^{\mathrm{b}}$ & $1.11^{\mathrm{b}}$ & 1.46 & 1.26 & $0.83^{b}$ & $1.27^{\mathrm{b}}$ & 1.41 & 1.08 & 1.24 & $2.16^{\mathrm{a}}$ \\
\hline $\mathrm{BH}$ & 1.29 & $1.50^{\mathrm{a}}$ & 1.39 & $2.20^{\mathrm{a}}$ & $1.60^{\mathrm{a}}$ & 1.95 & 1.37 & $2.15^{\mathrm{a}}$ & $1.58^{\mathrm{a}}$ & 1.43 & 1.46 & 1.53 & $1.20^{\mathrm{b}}$ \\
\hline$p$ & ns & 0.005 & ns & 0.007 & 0.006 & ns & ns & $<0.001$ & 0.003 & ns & ns & ns & 0.017 \\
\hline
\end{tabular}

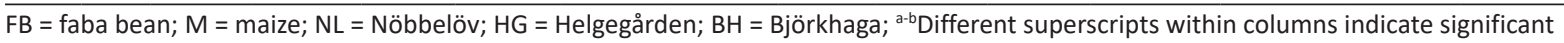
differences between cropping treatments, sites and their interaction $(p<0.05$, Tukey's HSD test)

\section{Discussion}

\section{Intercropping and acquisition of mineral nutrients}

Most of the analysed nutrient concentrations were within a common range of the two crops (Tables 2-5; NRC 2001, Spörndly 2003, Blackwood 2007). Concentrations of Ca, Fe and Mo were slightly higher and S slightly lower in the present investigation than reported previously for $\mathrm{FB}$. In maize, concentrations of $\mathrm{K}$ and $\mathrm{S}$ were lower while $\mathrm{Zn}$ was slightly higher here than reported earlier (NRC 2001, Spörndly 2003, Blackwood 2007). The differences in mineral nutrient concentrations in $\mathrm{FB}$ might be due to the fact that the whole $\mathrm{FB}$ plant was harvested at bean maturity $\mathrm{BBCH}$ 99 as compared with concentrations in the sole beans of monocropped FB plants in the earlier studies. For maize, earlier reported concentrations were found in silage of maize as compared to the fresh forage in the present investigation (NRC 2001, Spörndly 2003, Blackwood 2007). Intercropping maize and faba bean increased the efficiency of soil nutrient usage as the results showed that the total uptake of minerals per land area generally was greater than in monocrops (Table 9), resulting in increased total nutrient acquisition by the different functional traits of the two crop species. Also, the average concentration of several minerals, i.e. $\mathrm{K}, \mathrm{Ca}, \mathrm{Mg}, \mathrm{Na}, \mathrm{S}$ and $\mathrm{B}$ in faba bean and $\mathrm{Cu}, \mathrm{Zn}$ and $\mathrm{Mo}$ in maize increased in the intercropped treatments (Tables $2-5$ ). Increased concentrations of minerals may in some cases be due to the smaller yield of biomass found in intercropped treatments, as negative linear relationships were found between DM yield and mineral concentrations (Table 6). The relationships were not always negative; positive relationships or non existing relationships were also found, and they varied between sites and between different mineral nutrients. Thus, other processes such as a facilitative mineral acquisition may explain the higher mineral nutrient concentrations in intercropped treatments. Results from earlier investigations have shown that concentrations of $\mathrm{Zn}, \mathrm{Mn}$ and $\mathrm{Cu}$ in stalk and grain of maize may increase by intercropping, but also that the amount of applied P may influence the effect (Xia et al. 2013). The total yield of mineral nutrients of the intercrop treatment was never significantly lower than any of the other treatments (Tables 7 and 8). Hence, even though the total yield of biomass in the intercrop might be smaller than for example in MM, the nutrient yield was not reduced. Furthermore, the LER demonstrated that intercropping maize and faba bean increases the uptake of mineral nutrients compared with cultivating the two crops separately (Table 9). Thereby, the present results were in accordance with hypothesis i), i.e. that intercropping increases concentrations and total uptake of mineral nutrients in plant shoots per land area. The facilitative acquisition of mineral nutrients in intercropping systems might be due to alteration of the release of acid phosphatases and organic acids from the roots, which is affected by intercropping and also by soil nutrient status (Li et al. 2004a, Li et al. 2007, Hinsinger et al. 2011). 
Acid phosphatases may play an important role in the improvement of $\mathrm{P}$ acquisition under $\mathrm{P}$ deficient conditions according to Yadav and Tarafdar (2001). They also found that the amount of acid phosphatases secreted by legumes was $70 \%$ greater than by cereals. In the present investigation, the $\mathrm{P}$ availability was sufficient showing $\mathrm{P}$ shoot concentrations of $0.46 \%$ of DM in faba bean and $0.27 \%$ of DM in maize, and intercropping did not result in an increased acquisition. Previous studies, reported P shoot concentrations of $0.21-0.24 \%$ of DM in faba bean and $0.13-0.15 \%$ of DM in maize (Li et al. 2003, Li et al. 2010), which were much lower than in the present study indicating that the amount of available $P$ was sufficient. Thus, the beneficial effect of increased nutrient aquisition by various plant function traits was not found in the present study for $P$. The effect of intercropping on shoot concentrations of mineral nutrients varies between different field sites with varying soil properties, which is in accordance with the results of the present investigation (Li et al. 2004a, Li et al. 2007).

The total uptake of mineral nutrients per land area was greater in the intercropping system than in the monocropped systems for most of the minerals although there were some differences between the various field sites (Table 8). At HG, the low total nutrient LER $(<1)$ for $\mathrm{P}, \mathrm{Ca}$ and $\mathrm{Mn}$ was mainly due to the low yield of faba bean (Stoltz and Nadeau 2014). The mineral shoot concentrations of maize and faba beans were, in general, either unaffected or increased by intercropping. In maize, concentrations of $\mathrm{P}, \mathrm{Ca}$ and $\mathrm{Mn}$ at $\mathrm{HG}$ and concentrations of $\mathrm{N}, \mathrm{S}$ and $\mathrm{Mo}$ at $\mathrm{BH}$ decreased by intercropping. No reduction in mineral concentrations was found in faba bean. Plant species may not always gain the benefits of increased nutrient acquisition when intercropped. Earlier investigations show that the total uptake of $\mathrm{N}$ and $\mathrm{P}$ increased in wheat, when intercropped with soybean or maize, whereas the opposite was found in the soybean and in the maize plants (Li et al. 2001). Furthermore, the $\mathrm{N}$ capture was increased in faba bean when intercropped with maize compared with monocropped faba bean, while decreases in $\mathrm{N}$ capture were found in barley and wheat when intercropped with maize (Li et al. 2011), showing that plant species differ in their functional traits. Thus, maize and faba beans are, under most conditions, favoured by intercropping and the functional divergence effect contribute to an increased nutrient use efficiency of the arable land and the production of crops with higher contents of mineral nutrient essential for livestock.

In maize and faba bean produced for forage, an increase of mineral concentrations may contribute to a higher quality of feed and is vital for animal performance (McDowell 1996). Synthetic minerals are generally added in the diets but the organic minerals in forage are absorbed more efficiently by the animals than the synthetic forms (McDowell 1996). A ration containing maize silage needs more supplementation of synthetic minerals than a diet containing the maize/faba bean silage as the mineral concentrations were lower in the maize than in the faba bean demonstrating the ecological complementary effects of intercropping (NRC 2001).

\section{Intercropping and leaf spots in faba beans}

The severity of leaf spots in faba beans was reduced in intercropped plants in accordance with hypothesis ii) (Fig. 1). Reduced leaf spots may be due to the difference in physical plant traits altering the crop stand structure with a reduced host biomass and an altered microclimate that may prevent the spread of the disease (Harrison 1980, Fernández-Aparicio et al. 2011). Also, plant functional traits such as ability of decomposition of plant material may be more efficient in multispecies systems reducing the possibility of pathogen survival and also increasing the nutrient acquisition (Faucon et al. 2015). Other factors that influence the severity of chocolate spot are precipitation, time of sowing, and presence of weed that increase the humidity in the crop stand (Sahile et al. 2008a, 2008b). The severity of leaf spot DSI varied between sites, depending on local climate and cropping intensity. In this study plants with $\mathrm{Cu}$ shoot concentrations of 11-12 $\mathrm{mg} \mathrm{kg}^{-1}$ generally had lower disease severity index (DSI) than shoots with a Cu concentration of 7-9 $\mathrm{mg} \mathrm{kg}^{-1}$ (Fig. 2). Copper is a mineral that affect crop diseases, and can reduce the severity of e.g. leaf spots in lettuce and pea and leaf rust in wheat (Evans et al. 2007).

Intercropping faba bean and maize combine functional plant traits that seem to improve the acquisition of $\mathrm{Cu}$ in faba bean, when the availability was low. Even though the Cu concentration was not significantly affected by intercropping (Table 3), the increase in Cu acquisition tended to be greater when the Cu concentrations were generally lower, i.e. at $\mathrm{BH}$, while intercropping reduced $\mathrm{Cu}$ concentration slightly at $\mathrm{NL}$, with generally higher Cu concentrations. At sites with low levels of plant available $\mathrm{Cu}$, intercropping faba bean is likely to increase $\mathrm{Cu}$ acquisition thereby affecting plant resistance (Datnoff et al. 2007). Thus the functional traits differ between various soil conditions. 


\section{Conclusion}

We have shown that intercropping maize and faba bean for forage in organic production systems can increase nutrient use efficiency and generate a quality feed with higher mineral concentrations, thus increasing the ecosystem services. The severity of leaf spots was decreased by intercropping, probably due to a slightly increased $\mathrm{Cu}$ acquisition that can strengthen the plant, and to altered crop structure. Intercropping maize and faba bean can thereby, contribute to increased production efficiency and to sustainable agricultural systems.

\section{Acknowledgements}

This work was funded by The Swedish Farmers' Foundation for Agricultural Research, grant number H0960135K02, and Adolf Dahls foundation, grant number H14-0143-ADA. Thanks to the personnel at the Field Research Unit of the Rural Economy and Agricultural Societies (Hushållningssällskapet, Kristianstad). Thanks to Associate Professor Johannes Forkman at the Department of Crop Production Ecology, SLU, Uppsala, for statistical support. The authors declare that they have no conflict of interest.

\section{References}

Akhter, S. 2014. Interactions between Rhizobium, antagonistic bacteria and fungal pathogens in faba bean. Faculty of Natural Resources and Agricultural Sciences. Department of Forest Mycology and Plant Pathology, Master's thesis, -30 hec - Second cycle, A2E Biotechnology - Master's Programme Uppsala 2014. http://stud.epsilon.slu.se

Blackwood, I. 2007. Mineral contents of common ruminant stockfeeds, crops and pastures. Primefact 522. (c) State of New South Wales through NSW Department of Primary Industries 2007. ISSN 1832-6668. Collected from: www.dpi.nsw.gov.au

Datnoff, L.E., Elmer, W.H. \& Huber, D.M. 2007. Mineral nutrition and plant disease. The American Phytopathological Society. APS Press, USA. 278 p.

Dordas, C. 2008. Role of nutrients in controlling plant diseases in sustainable agriculture: A review. Agronomy of Sustainable Development 28: 33-46. https://doi.org/10.1051/agro:2007051

Engelhard, A.W. 1993. Soilborne plant pathogens: Management of diseases with macro- and microelements. The American Phytopathological Society, USA. 217 p.

Evans, I., Solberg, E. \& Huber, D.M. 2007. Copper and plant disease. In: Datnoff, L.E., Elmer, W.H. \& Huber, D.M. (eds.) Mineral nutrition and plant disease. The American Phytopathological Society, USA: APS Press. p. 177-188.

Faucon, M.-P., Houben, D. \& Lambers, H. 2017. Plant functional traits: Soil and ecosystem services. Trends in Plant Science 22: 385-394. https://doi.org/10.1016/j.tplants.2017.01.005

Faucon, M.-P., Houben, D., Reynoird, J.-P., Mercadal-Dulaurent, A.-M., Armand, R. \& Lambers, H. 2015. Advances and perspectives to improve the phoshprus availability in cropping systems for agroecological phosphorus management. Advances in Agronomy 134: 1-29. https://doi.org/10.1016/bs.agron.2015.06.003

Fernández-Aparicio. M., Shtaya, M.-J.Y., Emeran, A.A., Allagui, M.B., Kharrat, M. \& Rubiales, D. 2011. Effects of crop mixtures on chocolate spot development on faba bean grown in Mediterranean climats. Crop Protection 30: 1015-1023. https://doi. org/10.1016/j.cropro.2011.03.016

Gunes, A., Inal, A., Adak, M.S., Alpaslan, M., Bagci, E.G., Erol, T. \& Pilbeam, D.J. 2007. Mineral nutrition of wheat, chickpea and lentil as affected by mized cropping and soil moisture. Nutrient Cycling in Agroecosystems 78: 83-96. https://doi.org/10.1007/ s10705-006-9075-1

Harrison, J.C. 1980. Effect of environmental factor on growth of lesions on field bean leaves infected by Botrytis fabae. Annals of Applied Biology 95: 53-61. https://doi.org/10.1111/j.1744-7348.1980.tb03970.x

Hauggaard-Nielsen, H. \& Jensen, E.S. 2005. Facilitative root interactions in intercrops. Plant and Soil 274: 237-250. https://doi. org/10.1007/s11104-004-1305-1

Hinsinger, P., Betencourt, E., Bernard, L., Brauman, A., Plassard, C., Shen, J., Tang, X. and Zhang, F. 2011. P for two, sharing a scarce resource: soil phosphorus acquisition in the rhizosphere of intercropped species. Plant Physiology 156: 1078-1086. https://doi. org/10.1104/pp.111.175331

Huber, D.M. \& Haneklaus, S. 2007. Managing nutrition to control plant disease. Landbauforschung Volkenrode 57: 313-322.

Jannasch, R.W. \& Martin, R.C. 1999. The potential for capturing the forage yield of white lupin by intercropping with cereals. Biological Agriculture and Horticulture 17: 113-130. https://doi.org/10.1080/01448765.1999.9754831

Lancashire, P.D., Bleiholder, H., Langeluddecke, P., Stauss, R., van den Boom, T., Weber, E. \& Witzen-Berger, A. 1991. A uniform decimal code for growth stages of crops and weeds. Annals of Applied Biology 119: 561-601. https://doi.org/10.1111/j.1744-7348.1991. tb04895.x

Li, L., Li, S.-M., Sun, J.-H., Zhou, L.L., Bao, X.-G., Zhand, H.-G. \& Zhang, F.-S. 2007. Diversity enhances agricultural productivity via rhizosphere phosphorus facilitation on phosphorus-deficient soils. Proceedings of the National Academy of Sciences of the United States of America 104: 11192-11196. https://doi.org/10.1073/pnas.0704591104 
Li, S.M., Li L, Zhang, F.S., Tang, C. 2004a. Acid phosphatase role in chickpea/maize intercropping. Annals of Botany $94: 297-303$. https://doi.org/10.1093/aob/mch140

Li, H., Shen, J., Zhang, F., Marschner, P., Cawthray, G. \& Rengel, Z. 2010. Phosphorus uptake and rhizosphere properties of intercropped and monocropped maize, faba bean, and white lupin in acidic soil. Biology and Fertility in Soils 46: 79-91. https://doi. org/10.1007/s00374-009-0411-x

Li, Q.-Z., Sun J.-H., Wei X.-J., Christie P., Zhang F.-S. \& Li, L. 2011. Overyielding and interspecific interactions mediated by nitrogen fertilization in strip intercropping of maize with faba bean, wheat and barley. Plant and Soil 339: 147-161. https://doi.org/10.1007/ s11104-010-0561-5

Li, L., Sun, J., Zhang, F., Li, X., Yang, S. \& Rengel, Z. 2001. Wheat/maize or wheat/soybean strip intercropping I. Yield advantage and interspecific interactions on nutrients. Field Crop Research 71: 123-137. https://doi.org/10.1016/S0378-4290(01)00156-3

Li, L., Tang, C., Rengel, Z. \& Zhang, F.S. 2004b. Calcium, magnesium and microelement uptake as affected by phosphorus sources and interspecific root interactions between wheat and chickpea. Plant and Soil 261: 29-37. https://doi.org/10.1023/ B:PLSO.0000035579.39823.16

Li, L., Tilman, D., Lambers, H. \& Zhang, F.S. 2014. Plant diversity and overyielding: insights from belowground facilitation of intercropping in agriculture. New Phytology 203: 63-69. https://doi.org/10.1111/nph.12778

Li, L., Zhang, F., Li, X., Christie, P., Sun, J., Yang, S. \& Tang, C. 2003. Interspecific facilitation of nutrient uptake by intercropped maize and faba bean. Nutrient Cycling in Agroecosystems 65: 61-71. https://doi.org/10.1023/A:1021885032241

McDowell, L.R. 1996. Feeding minerals to cattle on pasture. Animal Feed Science and Technology 60: 247-271. https://doi. org/10.1016/0377-8401(96)00983-2

NRC 2001. Nutrient Requirements of Dairy Cattle, 7th revised Edition, National Academic Press, Washington, D.C. 408 p.

Sahile, S., Ahmed, S., Fininsa, C., Abang, M.M. \& Sakhuje, P. 2008a. Survey of chocolate spot (Botrytis fabae) disease of faba bean (Vicia faba L.) and assessment of factors influencing disease epidemics in northern Ethiopia. Crop Protection 27: $1457-1463$. https://doi.org/10.1016/j.cropro.2008.07.011

Sahile, S., Fininsa, C., Sakhuja, P.K. \& Ahmed, S. 2008b. Effect of mixed cropping and fungicides on chocolate spot (Botrytis fabae) on faba bean (Vicia faba) in Ethiopia. Crop Protection 27: 275-282. https://doi.org/10.1016/j.cropro.2007.06.003

Sillero, J.C., Villegas-Fernández, A.M., Thomas, J., Rojas-Molina, M.M., Emeran, A.A., Fernández-Aparicio, M. \& Rubiales, D. 2010. Faba bean breeding for disease resistance. Field Crop Research 115: 297-307. https://doi.org/10.1016/j.fcr.2009.09.012

Spörndly, R. 2003. Fodertabeller för idisslare. Rapport 257. Department of Animal Nutrition and Management, Swedish University of Agricultural Sciences, Uppsala, Sweden. (in Swedish).

Stoltz, E. \& Nadeau, E. 2014. Effects of intercropping on yield, weed incidence, forage quality and soil residual N in organically grown forage maize (Zea mays L.) and faba bean (Vicia faba L.). Field Crop Research 169: 21-29. https://doi.org/10.1016/j.fcr.2014.09.004

Weber, E. \& Bleiholder, H. 1990. Erläuterungen zu den BBCH-Dezimal-Codes für dieEntwicklungsstadien von Mais, Raps, FabaBohne, Sonnenblume und Erbse -mit Abbildungen. Gesunde Pflanzen 42: 308-321. (in German).

Yadav, J. \& Tarafdar, R. 2001 Influence of organic and inorganic phosphorus supply on the maximum secretion of acid phosphatase by plants. Biology and Fertility in Soils 34: 140-143. https://doi.org/10.1007/s003740100376

Xia, H.Y., Zhao, J.G., Sun, J.H., Xue, Y.F., Eagling, T., Bao, X.G., Zhang, F.S. \& Li, L. 2013. Maize grain concentrations and above-ground shoot acquisition of micronutrients as affected by intercropping with turnip, faba bean, chickpea, and soybean. Science China Life Sciences 56: 1-12. https://doi.org/10.1007/s11427-013-4524-y 